\title{
Improving models of forest nutrient export with equations that predict the nutrient concentration of tree compartments
}

\author{
Laurent Augusto $^{1 *}$, Céline Meredied ${ }^{2,3}$, Didier BerT ${ }^{3}$, Pierre TRICHET $^{2}$, Annabel Porté $^{2,3}$, \\ Alexandre Bosc ${ }^{2}$, Frédéric LAGANE ${ }^{2,3}$, Denis Loustau ${ }^{2}$, Sylvain PELlERIN ${ }^{1}$, Frédéric DANJON ${ }^{2,3}$, \\ Jacques RANGER ${ }^{4}$, Jacques GELPE ${ }^{2}$ \\ ${ }^{1}$ INRA, UMR1220 TCEM, BP81 F-33883 Villenave d'Ornon Cedex, France \\ 2 INRA, UR1263 EPHYSE, 69 route d'Arcachon, F-33612 Cestas Cedex, France \\ ${ }^{3}$ INRA, UMR1202 BIOGECO, 69 route d'Arcachon, F-33612 Cestas Cedex, France \\ ${ }^{4}$ INRA, UR1138 BEF, F-54280 Champenoux Cedex, France
}

Keywords:

nutrient /

tree dimension /

export /

Pinus pinaster

(Received 5 February 2008; accepted 2 August 2008)

Mots-clés :

nutriment /

dendrométrie de l'arbre /

exportation /

Pinus pinaster

\begin{abstract}
- The objective of this study was to explore the distribution of major nutrients $(\mathrm{N}, \mathrm{P}, \mathrm{K}, \mathrm{Ca}$ and $\mathrm{Mg}$ ) in the aboveground compartments of an intensively managed tree species (Pinus pinaster Ait.). A total of 53 trees were cut down in even-aged stands respectively 8, 16, 26, 32 and 40 years old. The nutrient concentrations of the aboveground compartments were analysed.

- Nutrient concentrations of foliage did not vary with any of the variables used, except needle age. Nutrient concentrations of living branches, stem bark, stem sapwood, stem heartwood, stemwood and stem decreased with increasing branch diameter, bark thickness, sapwood thickness and heartwood thickness, respectively. Beyond a certain value of the predictive variable (stem diameter $\approx 15 \mathrm{~cm}$; branch diameter $\approx 2.5 \mathrm{~cm}$ ), the concentration of all the nutrients stabilised.

- A 50 year-old pine stand was used to obtain a validation dataset for nitrogen concentration. For this nutrient, the regression relationships gave satisfactory estimates for most compartments (mean error $=12-25 \%)$ and particularly for the stem.

- A procedure is proposed to estimate the nutrient exports associated with harvests of Pinus pinaster biomass.
\end{abstract}

Résumé - Établissement d'équations prédisant la concentration en nutriments des compartiments de l'arbre en vue d'une amélioration des modèles d'exportation de nutriments par récolte de biomasse.

- L'objectif de cette étude est d'explorer la distribution des éléments majeurs (N, P, K, Ca, Mg) dans les compartiments aériens d'une essence gérée de manière intensive. Au total, 53 pins maritimes ( $P i$ nus pinaster Ait.) ont été abattus parmi des peuplements équiennes de 8, 16, 26, 32 et 40 ans.

- Les concentrations en nutriments du feuillage ne varient pas pour une classe d'âge d'aiguilles donnée. Les concentrations des branches vivantes, de l'écorce, de l'aubier et du duramen décroissent lorsque le diamètre ou l'épaisseur du compartiment considéré augmente. La concentration de l'ensemble des nutriments devient constante lorsque la variable prédictive (diamètre ou épaisseur) atteint une valeur plateau.

- Un jeu de données de validation pour les concentrations en azote, provenant d'un peuplement équienne de pins de 50 ans, permet de confirmer les performances satisfaisantes des modèles construits (erreur moyenne $=12-25 \%$ ) et en particulier pour le tronc.

- Une procédure d'estimation des exportations de nutriments associées aux récoltes de biomasse de Pinus pinaster est présentée.

\footnotetext{
* Corresponding author: laugusto@bordeaux.inra.fr
} 


\section{INTRODUCTION}

Due to global warming, there is increasing interest in energies that have limited impact on carbon balance. Plant biomass is an attractive energy source as the carbon emitted during the production of energy has already been fixed by the vegetation. The maximum biomass harvest is obtained by collecting all the tree compartments: branches, foliage, stumps, coarse roots and even litter. This high removal rate is now being applied more and more frequently in forests that are already intensively managed for wood production, for instance pine or eucalyptus stands (Nunez-Regueira et al., 2005).

Modifications in forest practices often have impacts on the functioning and durability of the ecosystem concerned. Even though the canopy represents a small percentage of the aerial biomass, it contains a large proportion of tree nutrients (Merino et al., 2005). Compared to stem-only harvesting, whole-tree harvesting increases biomass exports only by a few tens of percent, whereas nutrient exports are often increased two to seven fold, particularly exports of nitrogen and phosphorus (e.g. Thompson et al., 1986). Consequently, export of forest residues may have a negative impact on the nutrient balance of the ecosystem (Ranger et al., 2002) and subsequently on soil chemical properties (Johnson et al., 1991). Accurate estimation of nutrient removal based on the chosen strategy of biomass export is therefore crucial to adjust forest management to the resiliency of the site concerned.

An interesting method to reach this goal is to build direct allometric relationships to relate tree nutrient content to dendrometric variables (Thompson et al., 1986). However, tissue nutrient concentrations vary with the type of tissue (Meerts, 2002) and tree dimensions (André and Ponette, 2003). Tissue proportions and dimensions also vary with the age of the tree (Porté et al., 2002) as well as with management (Ilomaki et al., 2003). Therefore, when direct allometric relationships between the stem diameter and the total nutrient content of trees are used in a different context from where they were built, they can only give broad estimates. Rodriguez-Soalleiro et al. (2007) thus proposed coupling models of the biomass production of each tree compartment with its mean nutrient concentration. This method is based on the assumption that, at the scale of the tree, nutrient concentrations in one tree compartment do not vary significantly from site to site. This hypothesis was validated on four tree species, provided that stands were mature (Augusto et al., 2000). This limitation implies that simple models underestimate exports of nutrients from young stands, which have systematically higher concentrations than mature stands. Moreover, results of a previous study showed that, while the mean concentrations of nutrients in the stem bole (including bark) were relatively constant among sites, those for total aboveground biomass were more variable (Augusto et al., 2000). This scattering was possibly due to some heterogeneity in the nutrient concentrations of the canopy. Therefore, equations relating nutrient concentrations in any tree compartment and at any age are essential to ensure the reliability of simple models for any life stage of the stand. The objective of the present study was to build these equations for a well-documented tree species, maritime pine.
The species and the nutrients we studied are the same as those studied by Rodriguez-Soalleiro et al. (2007), namely maritime pine, nitrogen, phosphorus, potassium, calcium and magnesium. Coupling the two works could extend the range of tree age for which the models give accurate and reliable estimates of nutrient exports.

\section{MATERIALS AND METHODS}

\subsection{Study species and study region}

The natural area of maritime pine (Pinus pinaster Ait.) is mainly the Atlantic and Mediterranean coasts of Europe. Monospecific stands of maritime pine represent a surface area of approximately 4 Mha in Europe, mostly in Spain, France, and Portugal, and to a lesser extent, in Italy. Due to its ability to grow on very poor soils, this species has been widely introduced in some areas of the world with unfertile soils, provided that the climate is appropriate. These areas account for around 0.25 additional Mha, mainly in South Africa, New Zealand, Australia and Chile. In many of these areas, Pinus pinaster stands are intensively managed for wood production.

The present study was conducted in south-western France, where close to 0.90 Mha of even-aged stands of maritime pine constitute the 'Landes de Gascogne' forest. The parent material of the soils is the uppermost geological layer of the study region and is almost completely composed of coarse sand. Soils are poor, acidic and quite organic. They vary from typic haplorthod spodosols to haplohumod spodosols (or umbric endoaquod spodosols; USDA classification), depending of the depth of the water table. The regional site classification shows four main classes, the wettest (wet moorland) being the most frequent class.

\subsection{Study sites and trees}

The study was carried out in three even-aged Pinus pinaster stands (BERG-I; BERG-II; BRAY). BERG-I and BERG-II were located

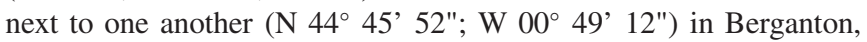
approximately $20 \mathrm{~km}$ southwest of the city of Bordeaux. BRAY was located about five kilometres from the other stands. The stands were originally sown on previously ploughed and fertilised soil (120 kg$\mathrm{P}_{2} \mathrm{O}_{5} \cdot \mathrm{ha}^{-1}$ ). Management was similar in all stands (target rotation length $\cong 40$ years preceded by four commercial thinnings). The three stands were located on the same soil type (typic haplohumod spodosols) and site class (wet moorland). Soils were sandy (sand $\geq 91 \%$; coarse sand $\geq 81 \%$ ), acidic ( $\mathrm{pH}-\mathrm{H}_{2} \mathrm{O}=3.9-4.3$, in the topsoil horizon), with a low base saturation of the cationic exchange capacity (upper horizons $=28-38 \%$; deeper horizons $=4-17 \%$ ). The soils were similar in all the stands and representative of the study region (data not shown). According to yield tables for French forests and the mean height of our stands (Tab. I), we concluded that BERG-I, BERG-II and BRAY had a similar growth rate and that these stands represented a valid chronosequence.

Five samplings were carried out. BERG-I stand was sampled at 16,32 and 40 years-old for determination of nutrient concentrations (B16, B32 and B40 samplings; see Lemoine et al., 1988 for more details on B16). BERG-II and BRAY were sampled at 8 and 26 yearsold respectively (B08 and B26). All samplings were carried out in wintertime since concentrations of foliage nutrients undergo seasonal variations during the growth period (Wyttenbach and Tobler, 1988). 
Table I. Characteristics of the sampled stands and sampling operations. $\mathrm{CBH}=$ circumference at breast height; $\mathrm{Bk}=\mathrm{stem}$ bark; $\mathrm{Phl}=$ stem phloem; $\mathrm{SpWd}=$ stem sapwood; HtWd = stem heartwood; $\mathrm{DBr}=$ dead branches; $\mathrm{LBr}=$ living branches; Ndl1 = one-year-old needles; $\mathrm{ND}_{2}{ }^{+}=$needles more than one-year-old; $\mathrm{Bd}=$ buds; $\mathrm{Co}=$ cones. Values: mean \pm 1 standard error.

\begin{tabular}{|c|c|c|c|c|c|c|c|c|c|c|c|c|c|c|c|c|c|c|}
\hline \multirow[t]{2}{*}{$\begin{array}{l}\text { Sampled } \\
\text { stand }\end{array}$} & \multirow[t]{2}{*}{$\begin{array}{l}\text { Sampling } \\
\text { operation }\end{array}$} & \multirow{2}{*}{$\begin{array}{c}\text { Age at } \\
\text { sampling } \\
\text { (y) }\end{array}$} & \multirow[t]{2}{*}{$\begin{array}{c}\text { Year of } \\
\text { sampling }\end{array}$} & \multirow{2}{*}{$\begin{array}{c}\text { Number of } \\
\text { trees } \\
\text { sampled }\end{array}$} & \multirow{2}{*}{$\begin{array}{c}\text { Stand } \\
\text { density } \\
\left(\text { tree.ha }^{-1}\right)\end{array}$} & \multirow{2}{*}{$\begin{array}{l}\text { Mean } \\
\text { height } \\
(\mathrm{m})\end{array}$} & \multirow{2}{*}{$\begin{array}{l}\text { Mean } \\
\text { CBH } \\
(\mathrm{cm}) \\
\end{array}$} & \multicolumn{10}{|c|}{$\begin{array}{c}\text { Compartments analysed } \\
\text { (number of samples) }\end{array}$} & \multirow{2}{*}{$\begin{array}{c}\text { Number } \\
\text { of } \\
\text { samples }\end{array}$} \\
\hline & & & & & & & & $\mathrm{Bk}$ & Phl & SpWd & HtWd & $\mathrm{DBr}$ & $\mathrm{LBr}$ & Ndl1 & $\mathrm{NDl}^{+}{ }^{+}$ & $\mathrm{Bd}$ & $\mathrm{Co}$ & \\
\hline \multirow[t]{3}{*}{ BERG-I } & B16 & 16 & 1979 & 11 & 817 & $11.8 \pm 0.3$ & $59 \pm 3$ & 62 & . & 62 & . & 11 & 89 & 89 & 77 & 88 & . & 478 \\
\hline & B32 & 32 & 1995 & 10 & 337 & $21.9 \pm 0.4$ & $122 \pm 5$ & 68 & 68 & 70 & 55 & 30 & 48 & 48 & 48 & 26 & 17 & 478 \\
\hline & B40 & 40 & 2003 & 8 & . & $23.8 \pm 0.5$ & $139 \pm 7$ & 70 & . & 62 & 47 & . & . & . & . & . & . & 179 \\
\hline BERG-II & B08 & 8 & 2003 & 10 & 1574 & $6.1 \pm 0.2$ & $28 \pm 2$ & 20 & . & 20 & . & . & 10 & 10 & 10 & . & . & 70 \\
\hline BRAY & B26 & 26 & 1995 & 14 & 621 & $17.0 \pm 0.3$ & $82 \pm 4$ & 52 & 22 & 63 & 51 & . & 101 & 39 & 74 & . & . & 402 \\
\hline BILOS & B50 & 50 & 2000 & 12 & 223 & $20.7 \pm 0.4$ & $118 \pm 5$ & 32 & 32 & 36 & 27 & 4 & 14 & 14 & 27 & 12 &. & 198 \\
\hline
\end{tabular}

At each site, the circumference at breast height $(\mathrm{CBH})$ of all living trees was measured and 8-14 trees representing all the dimension classes were cut down. Total tree height was measured. Along the stem, "annual shoots" (the vertical fraction of the stem formed during one growing season) were measured along with their length and their mid-length circumference. The cambial age of each annual shoot was determined by numbering them in ascending order from the top of the tree (cambial age $=1)$ to the soil (cambial age $=$ age of the tree).

\subsection{Tree sampling for nutrient analysis}

An intensive study of carbon concentration in Pinus pinaster confirmed the relevance of a sampling design that split the stem into homogeneous tissues (Bert and Danjon, 2006). Indeed, based on the knowledge of the concentration of one element at the tissue scale, such an approach enables the average concentration of the stem to be determined. A similar sampling design was thus used in the present study.

Stems were sampled either by cutting a 5- to $10 \mathrm{~cm}$-thick disk in the middle of the annual shoot, or, in the case of B32, by collecting several wood cores (in the N, W, S, E directions) in the middle of the annual shoot using a Pressler's increment borer (diameter $=5 \mathrm{~mm}$ ). Stem annual shoots were sampled either at regular increments of cambial age (B08 and B32) or at the same distance from each other (2.0-2.5 m; B16, B26 and B40). Stem samples were split into heartwood, sapwood, phloem and bark, then oven-dried at $65^{\circ} \mathrm{C}$ to constant weight.

Living branches were collected along the stem either at regular increments of cambial age or at regular intervals. The diameter of living branches was measured $10 \mathrm{~cm}$ from their base. The wood, phloem and bark of living branches were not separated and from now on, all are referred to as "living branches" (LBr). The whole branch was harvested except in the case of B26 where only the apex of each living branch was sampled (the diameter was measured $10 \mathrm{~cm}$ from the cut). In BERG-I, no branch from the B40 sampling was analysed because the tree canopy was exposed to intense sunlight due to the windthrows that had occurred three years previously, which we considered being likely to introduce a bias.

Keay et al. (1968) and Monge (1970) showed that nutrient concentrations in one-year-old needles differed significantly from those in older needles. We consequently split needles into two groups: oneyear-old needles (Ndl1), and needles that were more than one year old $\left(\mathrm{Ndl} 2^{+}\right)$, the latter group mainly comprised two-year-old needles (Porté et al., 2000).

In B16 and B32 sampling operations, some dead branches (DBr), buds (Bd) and cones (Co) were also collected for analysis. Individual samples of dead branches were bulked into one composite sample per tree.

\subsection{Chemical analyses}

A total of 1607 samples were prepared for the determination of total $\mathrm{N}, \mathrm{P}, \mathrm{K}, \mathrm{Ca}$ and $\mathrm{Mg}$ concentrations (Tab. I). Except for buds and needles, the samples were first crushed (mesh size $\cong 1 \mathrm{~cm}$ ) and then homogenised. Then an aliquot (10-300 g) from each sample was ground (mesh size $=0.5 \mathrm{~mm}$ ) before analysis.

$\mathrm{N}$ concentration was determined by thermal conductimetry. For $\mathrm{P}$, $\mathrm{K}$, $\mathrm{Ca}$ and $\mathrm{Mg}$, the analyses were performed by dry nitric acid digestion followed by ICP spectrophotometry quantification calibrated with certified references. For all elements, the quality of the analyses performed in the laboratory (INRA-USRAVE) was checked by participating to a few laboratory ring tests (ICP-FOREST; IPE). All the tests $(n=108)$ for the nutrients considered in our study were correct: $\left|\left(\bar{x}_{\text {ring }}-\bar{x}_{\text {lab }}\right) / \sigma_{\text {ring }}\right|<2$. The samples analysed in the $1980 \mathrm{~s}$ (B16) were digested with perchloric acid, except for the samples used for determination of $\mathrm{N}$, which were digested with sulphuric acid. $\mathrm{N}$ and $\mathrm{P}$ were quantified using a colorimetric method. $\mathrm{K}, \mathrm{Ca}$ and $\mathrm{Mg}$ were quantified with an atomic absorption spectrometer. Some of the 1980s samples (mainly wood P concentration) were between the limit of quantification and the limit of detection and were consequently discarded. Results of $\mathrm{P}$ concentrations obtained after perchloric acid mineralisation (B16 sampling) rather than after nitric acid mineralisation (B08-B26-B32-B40 samplings) were slightly corrected $(-12 \%)$ based on the results of an intercalibration test (Daniel et al., 1993). Sampling stemwood with the increment borer method has been shown to introduce some bias in the estimation of nutrient concentrations (Augusto and Bert, 2005). The concentration values of sapwood and heartwood were consequently corrected (from $-12 \%$ to $+15 \%$ ) when the increment borer method was used (B32 sampling). As the corrections were of low magnitude and concerned only a few compartments in two samplings, their impact on the final mean concentrations was slight (e.g. sapwood: $\mathrm{N}=+2.4 \%, \mathrm{P}=+5.4 \%, \mathrm{~K}$ $=+2.5 \%$; heartwood: $\mathrm{Ca}=-4.1 \% ; \mathrm{Mg}=-3.4 \%$; stem bark: $\mathrm{P}=$ $-4.5 \%$ ). The parameters of the regression relationships were not significantly modified by the corrections of the concentrations (data not shown).

\subsection{Measurement or estimation of the dimensions of the stem compartment}

The image of one transversal section of each stem disk was digitalized for half of the stem samples. Heartwood thickness $\left(\mathrm{T}_{\text {heartwood }}\right)$, 
sapwood thickness $\left(\mathrm{T}_{\text {sapwood }}\right)$, phloem thickness $\left(\mathrm{T}_{\text {phloem }}\right)$, and bark thickness $\left(\mathrm{T}_{\text {bark }}\right)$ were measured in the $\mathrm{N}, \mathrm{W}, \mathrm{S}, \mathrm{E}$ direction (stem radius $=\mathrm{T}_{\text {heartwood }}+\mathrm{T}_{\text {sapwood }}+\mathrm{T}_{\text {bark }}+\mathrm{T}_{\text {phloem }}$ ) using dedicated software. Mean quadratic thickness was calculated for each type of tissue of the disk. Measurements were carried out on half of the samples. For the other half of the stem samples, $\mathrm{T}_{\text {heartwood }}, \mathrm{T}_{\text {bark }}$, and $\mathrm{T}_{\text {phloem }}$ were estimated according to allometric relationships fitted and validated in the study region (Bert, unpublished data; Appendix 1). $\mathrm{T}_{\text {sapwood }}$ was simply estimated according to stem circumference under the bark and $\mathrm{T}_{\text {heartwood }}$. The estimates were then validated using the set of measured values: no significant deviation was observed between estimated and measured values.

For each stem sample, the mean concentration of each nutrient was calculated for stem and stemwood. Here, "stem" is defined as the disk section of the trunk that included all tissues (heartwood + sapwood + phloem + bark) whereas "stemwood" consisted of the same section but only included the wood tissues (heartwood + sapwood). Before calculating the mean nutrient concentration, the concentration of each compartment was weighted according to its density and volume in the sample.

The mean concentration of nutrients in the stem (heartwood + sapwood + phloem + bark) was also calculated at the tree scale. To this end, the mean concentration of nutrients in all annual shoots of the stem was calculated. To take into account the contribution of the different annual shoots to the stem biomass, the concentration of each annual shoot was weighted by the shoot biomass for the calculation of the mean concentration. As the nutrient concentration was not measured in all the annual shoots, the mean concentration of the stem at the tree scale was calculated according to the regressions established for at the annual shoot scale (R1 regressions: see below).

\subsection{Statistical analyses and evaluation}

The statistical analyses were computed with SAS-STAT software (SAS Institute Inc., NC-USA). Analysis of variance (ANOVA) was performed to assess tree age, tissue dimension and individual tree effects and interactions. Since values of nutrient concentration may be nested (e.g. by individual tree), we then used a mixed linear model with tree age, tissue dimension and age $\times$ dimension effects as fixed effects and individual trees as random effects. The outcome of both the generalised linear model (ANOVA) and the mixed linear model were very similar, but we preferred the mixed linear model in order to account for a possible nesting effect of the concentration values. The Bonferroni adjustment in the Least Squares Means Differences procedure was used to assess the differences between classes for a given variable. The significance levels cited throughout this paper refer to these Bonferrroni adjusted P levels.

Independent variables used to predict nutrient concentrations were tree dimensions (height; circumference at breast height), tree social status defined as 'tree $\mathrm{CBH} /$ mean $\mathrm{CBH}$ of the stand', dimensions of the tree compartments (basal branch diameter; compartment thickness), cambial age, and the position of the sample in the tree (sample height; relative height; distance to the tree top).

Two types of regression were built.

$\mathrm{R} 1:[$ nutrient $]=\alpha_{1} \cdot(\text { dendrometric variable })^{\beta_{1}}$

with $\alpha_{1}>0$ and $\beta_{1}<0$

$\mathrm{R} 2:[$ nutrient $]=\frac{\left(\alpha_{2} \cdot(\text { dendrometric variable })+\beta_{2}\right)}{\left((\text { dendrometric variable })+\gamma_{2}\right)}$

The $\mathrm{R} 1$ regression can be fitted for most regular non-linear curves, but it gives unrealistic nutrient concentrations $(0$ and $+\infty)$ for extreme dendrometric values $(+\infty$ and 0$)$. Conversely, the $\mathrm{R} 2$ regression enables calculation of acceptable concentration values $\left(\alpha_{2}\right.$ and $\left.\beta_{2} / \gamma_{2}\right)$ for extreme dendrometric values ( $+\infty$ and 0$)$.

The regression efficiency $(R E)$ was quantified as follows:

$$
R E=1-\frac{\sum\left(y_{i}-\hat{y}_{i}\right)^{2}}{\sum\left(y_{i}-\bar{y}\right)^{2}}
$$

where $\bar{y}$ is the mean of observed values, $y$ is the observed value and $\hat{y}$ the simulated value.

$R E$ ranges from 0 (regression not better than $\bar{y}$ ) to 1 (perfect relationship).

An independent validation dataset of $\mathrm{N}$ concentration was used for validation. The set was taken from unpublished data from a previous study (Bert and Danjon, 2006). Briefly, the dataset included 198 measurements of nitrogen concentration in 12 Pinus pinaster trees growing in a 50-year-old stand (BILOS stand; B50 sampling; Tab. I). This stand was also located on wet moorland but was less productive. The error of prediction was calculated for each compartment as follows:

$$
\text { Error }=\frac{\left|[N]_{\text {predicted }}-[N]_{\text {measured }}\right|}{[N]_{\text {measured }}} \times 100 \text {. }
$$

\section{RESULTS}

\subsection{Nutrient concentrations}

\subsubsection{General ranking of the tissues}

Mean concentration values per compartment are presented in Table II. Based on their nutrient concentrations, the aboveground compartments generally ranked as follows: buds > needles $>$ (phloem; branches; cones; stem bark) $>$ stemwood.

\subsubsection{Stem and stem tissues}

No significant relationship appeared between the nutrient concentration of the stem phloem and any variable (or any combination of variables) tested, namely tree dimensions (height; circumference at breast height), tree social status, the dimension of the tree compartment (phloem thickness), cambial age, and the position of the sample in the tree (sample height; relative height; distance to the top of the tree).

For the other stem tissues (bark, sapwood and heartwood), the concentrations of the five nutrients investigated varied with increasing stem tissue thickness (Figs. 1 and 2; mean values in Tab. II). Globally, concentrations decreased with increasing stem tissue thickness. Logically, aggregating tissues into composite compartments (stemwood and stem) also showed decreasing nutrient concentrations with increasing stem diameter (Fig. 3). No clear effect of tree age or cambial age was detected, even if some interactions with tissue dimension were significant. However, these interactions were mostly due to a site effect and were not confirmed by the validation dataset.

One notable observation was that nutrient concentrations stabilized at a certain stem diameter, even when the stem diameter continued to increase. This plateau value was reached for a stem diameter of around $10 \mathrm{~cm}$ and $15 \mathrm{~cm}$ for stemwood 


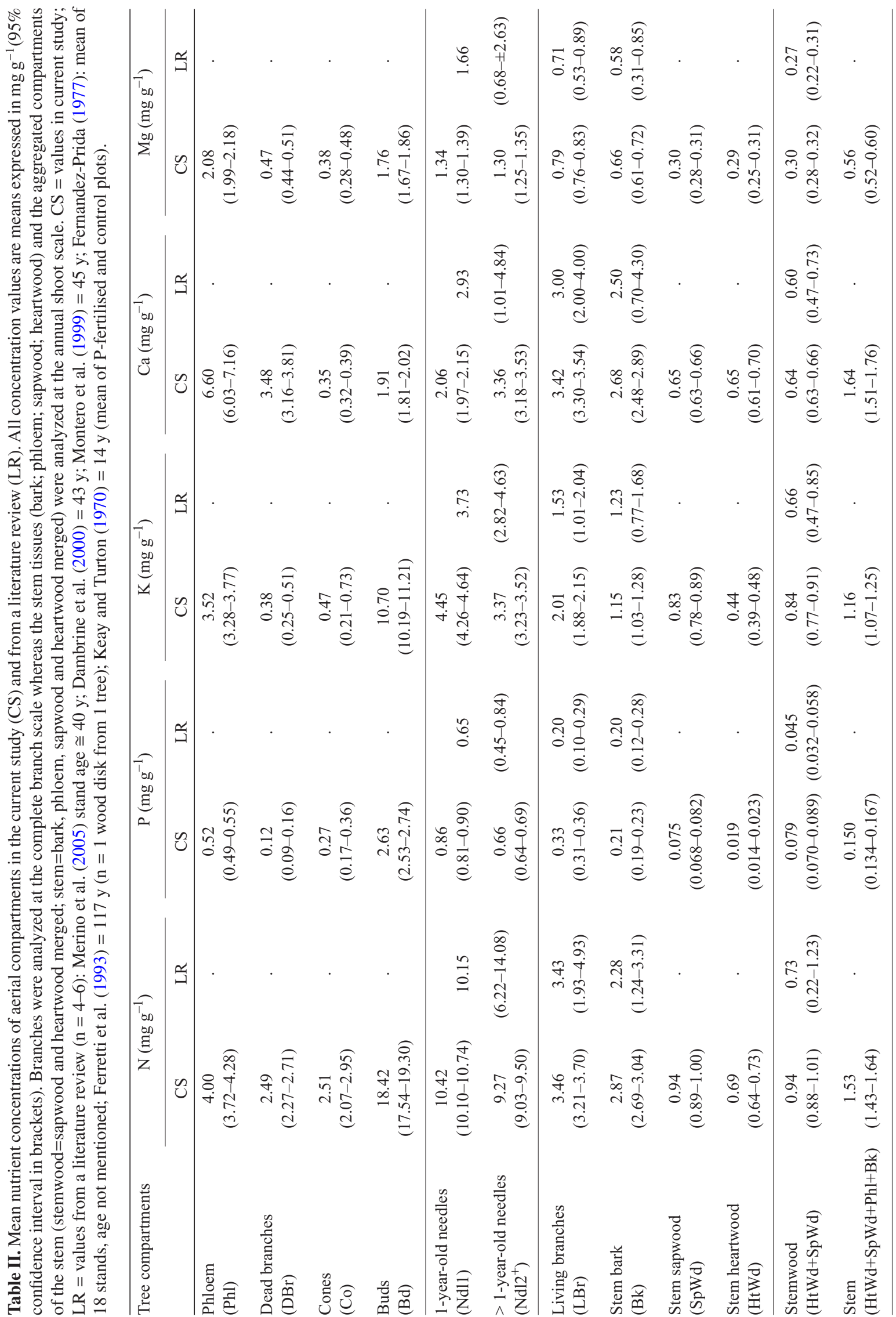


and stem (mean plateau values for stem: $0.94 \pm 0.03 \mathrm{mg}-\mathrm{N} . \mathrm{g}^{-1}$; $0.061 \pm 0.003 \mathrm{mg}-\mathrm{P} . \mathrm{g}^{-1} ; 0.73 \pm 0.03 \mathrm{mg}-\mathrm{K}_{\mathrm{g}} \mathrm{g}^{-1} ; 0.94 \pm 0.02 \mathrm{mg}-$ Ca. $\left.{ }^{-1} ; 0.32 \pm 0.01 \mathrm{mg}-\mathrm{Mg}^{-\mathrm{g}^{-1}}\right)$, respectively. This limit corresponded to a distance from the top of the tree of around $4.5 \mathrm{~m}$ and $8.0 \mathrm{~m}$ for stemwood and stem, respectively.

\subsubsection{Living branches}

As was the case in stem tissues, nutrient concentrations in living branches decreased with increasing branch diameter (Figs. 1 and 2; mean values in Tab. II). Variations in nutrient concentrations were more pronounced in branches than in stem tissues. Nutrient concentrations in living branches were clearly not correlated with the cambial age of the stem but with branch diameter (see for example $\mathrm{N}$ concentration in Fig. 4). No clear effect of tree age was detected.

In living branches, nutrient concentrations reached a plateau value at a branch diameter of around $2.5 \mathrm{~cm}$ (mean plateau values for living branches: $2.48 \pm 0.07 \mathrm{mg}-\mathrm{N} . \mathrm{g}^{-1}$; $0.22 \pm 0.01 \mathrm{mg}-\mathrm{P} . \mathrm{g}^{-1} ; 1.45 \pm 0.05 \mathrm{mg}-\mathrm{K}^{-g^{-1}} ; 3.22 \pm 0.08 \mathrm{mg}-$ Ca. $\left.{ }^{-1} ; 0.66 \pm 0.02 \mathrm{mg}-\mathrm{Mg} . \mathrm{g}^{-1}\right)$. This diameter class was observed $2-6 \mathrm{~m}$ below the top of the tree.

\subsubsection{Needles, buds, cones and dead branches}

Among needles, one-year-old needles (Nd11) were significantly richer in $\mathrm{N}, \mathrm{P}$ and $\mathrm{K}$ than older needles $\left(\mathrm{Ndl1} / \mathrm{Ndl}^{+}\right.$ ratio: $\mathrm{N}=1.12 ; \mathrm{P}=1.30 ; \mathrm{K}=1.32$ ), while the opposite result was obtained for calcium (ratio $=0.61$ ). The concentration of magnesium did not vary with needle age.

No significant relationship was observed between the nutrient concentration of each needle age class and any variable (or combination of variables) tested. The same results were obtained for buds and dead branches. Consequently, the nutrient concentrations of these compartments were considered to be constant in our study context. The concentrations of $\mathrm{P}, \mathrm{K}$ and $\mathrm{Mg}$ in the cones increased from the bottom to the top of the crown (data not shown).

\subsubsection{Comparison of the two types of regressions}

The two types of regressions were adjusted as a function of branch diameter or compartment thickness. In most cases, the $\mathrm{R} 2$ regression type was very slightly more efficient than the R1 regression type. However, in the case of a very steep relationship slope, R2 parameters were not adjustable. In certain other cases, R2 gave illogical parameters such as negative $\alpha_{2}$. In these latter cases, we retained R1 while in the other cases, we preferred $\mathrm{R} 2$ to $\mathrm{R} 1$. The parameters of these regressions are summarized in Table III. The shape of the relationship varied with the nutrient. Nitrogen, phosphorus and potassium concentrations decreased steeply with increasing tissue dimensions (Figs. 1 and 2 ) resulting in very negative $\beta_{1}$ parameters. The variations in calcium concentrations were slight (Fig. 2), except in stem bark. Magnesium concentrations displayed intermediate behaviour between calcium and other nutrients.
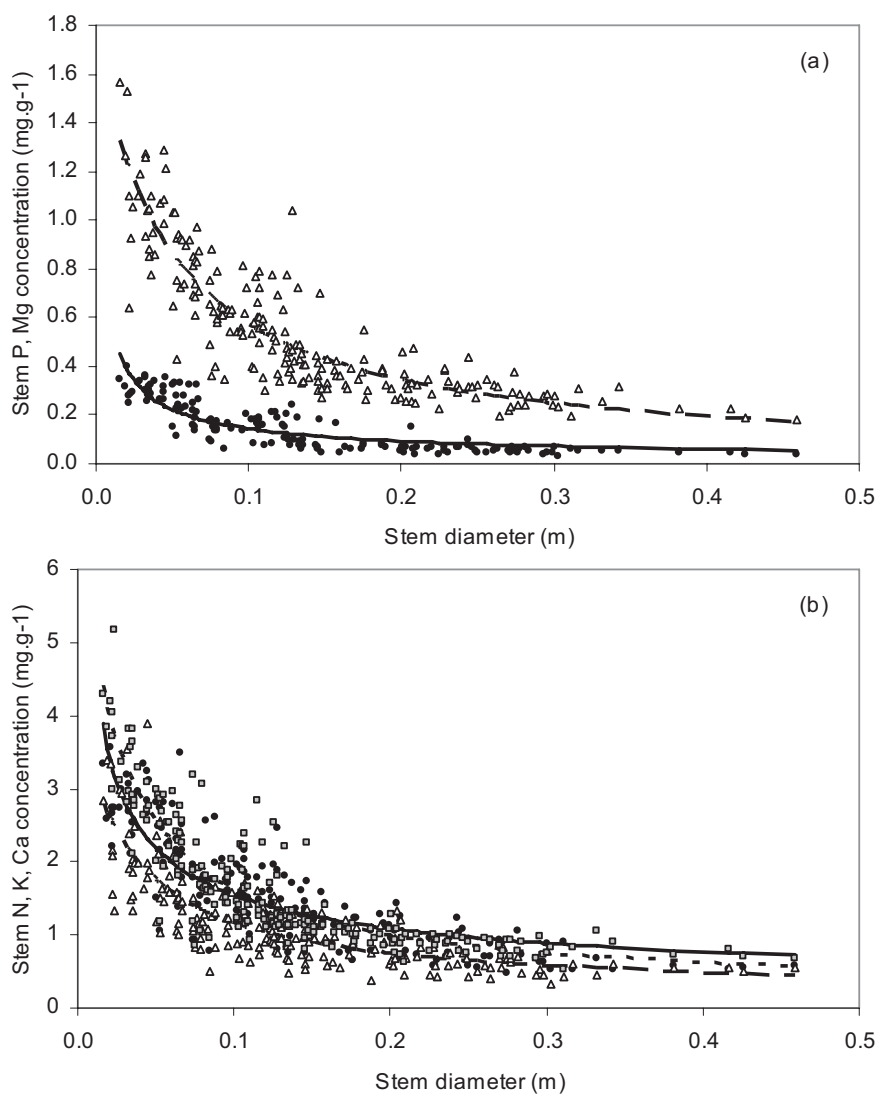

Figure 3. Relationships between nutrient concentration $\left(\mathrm{mg} \mathrm{g}^{-1}\right)$ of the stem (all stem tissues combined) of an annual shoot and the stem diameter (m) of the same annual shoot. (a) Measured P concentration = closed circle; measured $\mathrm{Mg}$ concentration = open triangle; regression function for $\mathrm{P}=$ solid line; regression function for $\mathrm{Mg}=$ dashed line. (b) Measured N concentration = closed circle; measured $\mathrm{K}$ concentration $=$ open triangle; measured $\mathrm{Ca}$ concentration $=$ grey square; regression function for $\mathrm{N}=$ solid line; regression function for $\mathrm{K}=$ dashed line; regression function for $\mathrm{Ca}=$ dotted line. The parameters of the regression functions are summarized in Table III.

\subsection{Validation of the nitrogen results}

We used the independent 50-year-old tree dataset to evaluate our regression relationships for $\mathrm{N}$ concentrations. For the branch, stem bark and sapwood compartments, the previously established regressions were mainly correct (mean error of prediction $=20 \%, 14 \%$ and $23 \%$, respectively). The $\mathrm{N}$ concentrations in the heartwood in the validation dataset showed values around the upper limit of the confidence interval (mean error $=32 \%$ ). The regression relationships established for $\mathrm{N}$ concentration in aggregated compartments (stem and stemwood) were consistent (mean error $=19 \%$ and $28 \%$, respectively) with the validation dataset (Fig. 5).

For compartments with constant concentrations, comparison of the validation dataset with the calibration dataset (Tab. II) gave quite satisfactory results for buds (validation dataset: $15.25 \pm 0.77 \mathrm{mg}-\mathrm{N} . \mathrm{g}^{-1}$ ), one-year-old needles (10.37 \pm 

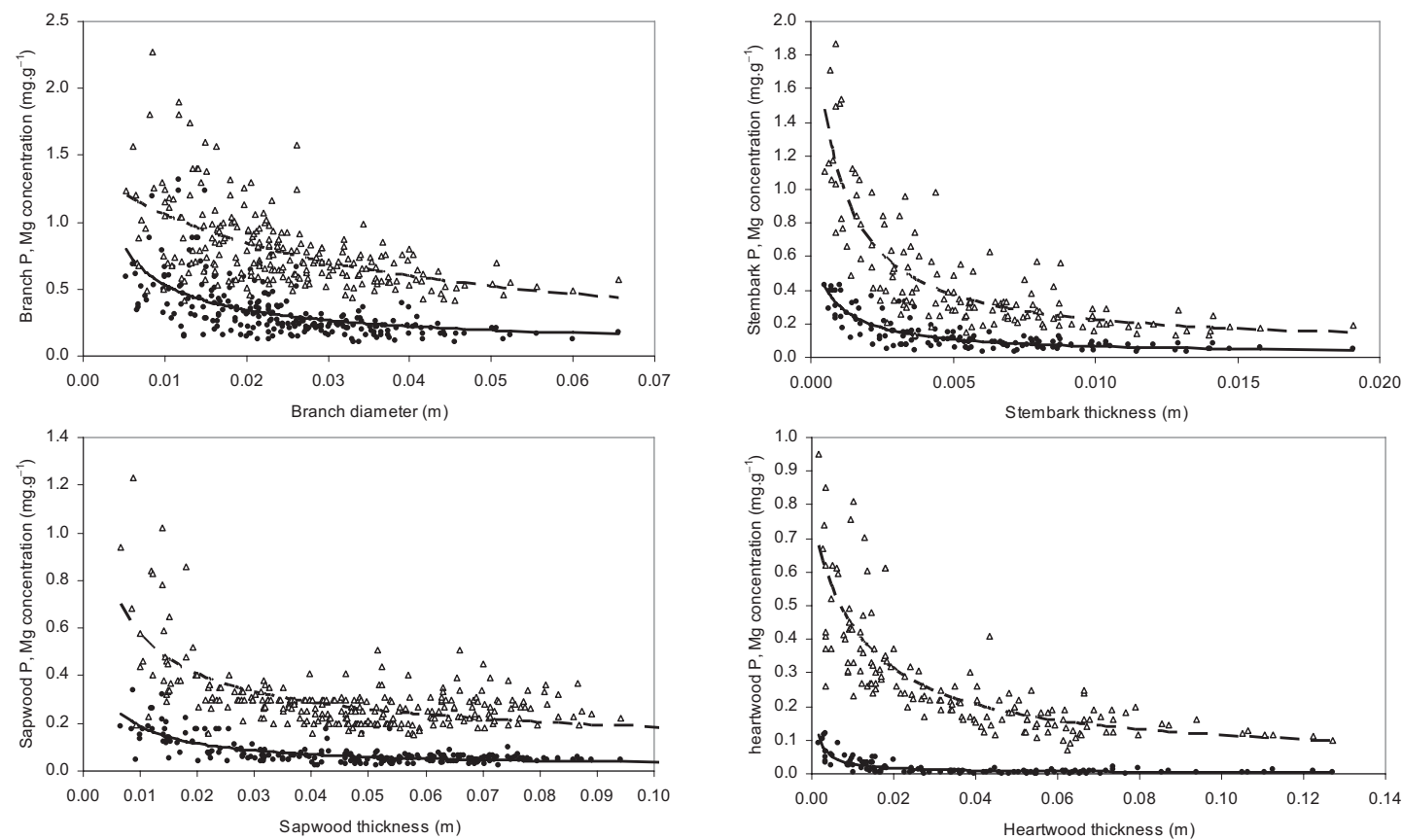

Figure 1. Relationships between $\mathrm{P}$ or Mg concentrations of living branches or stem tissues (bark, sapwood or heartwood) and the dimensions of the same compartment. Measured $\mathrm{P}$ concentration = closed circle; measured $\mathrm{Mg}$ concentration = open triangle; regression function for $\mathrm{P}=$ solid line; regression function for $\mathrm{Mg}=$ dashed line. Dimensional predicting variable = branch diameter (m) or stem tissue (bark; sapwood; heartwood) thickness (m). Branches were analyzed at the complete branch scale whereas the stem tissues (bark; phloem; sapwood; heartwood) were analyzed at the annual shoot scale. Nutrient concentration values are expressed as $\mathrm{mg} \mathrm{g}^{-1}$. The parameters of the regression functions are summarized in Table III.
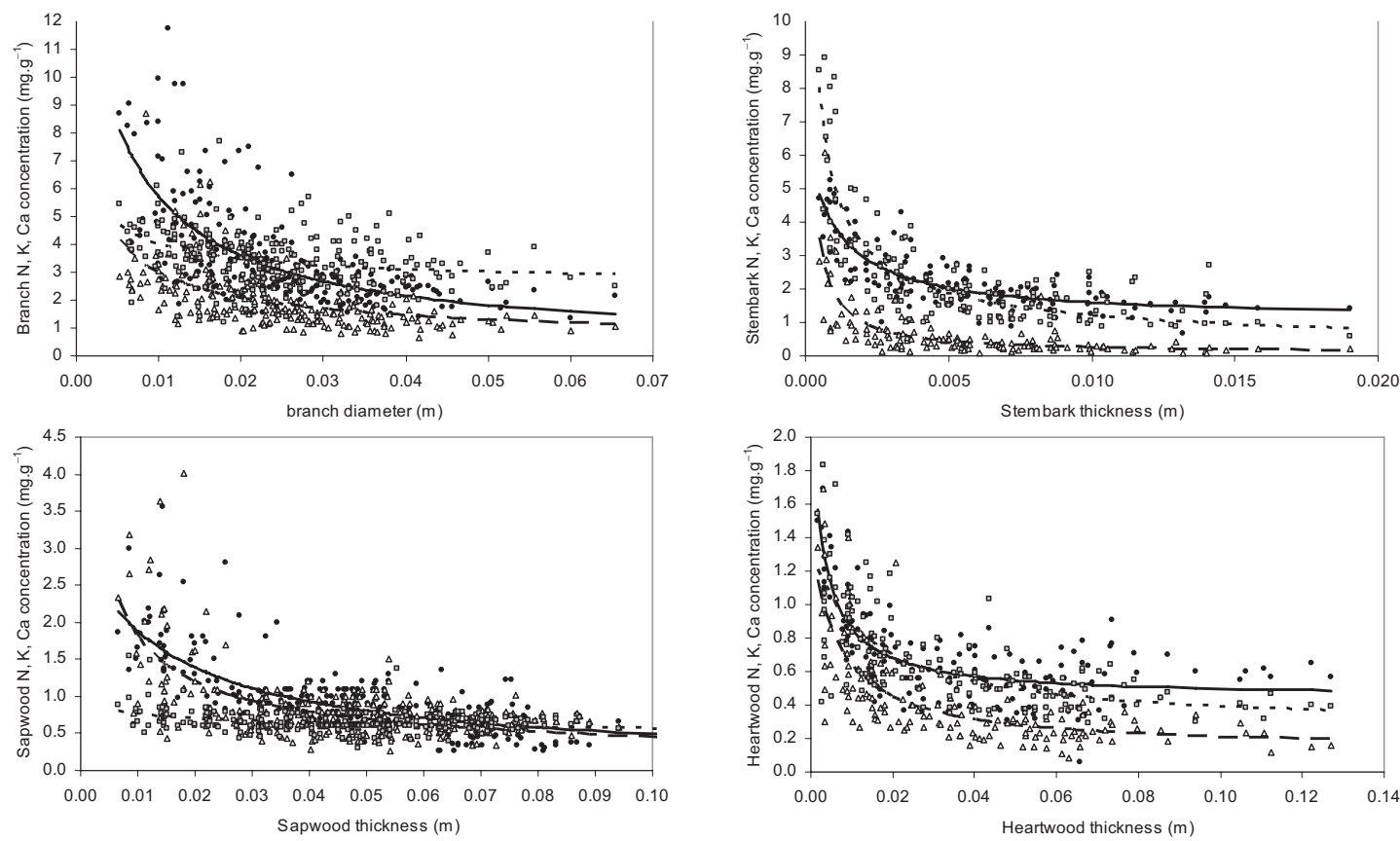

Figure 2. Relationships between N, K or Ca concentrations of living branches or stem tissues (bark, sapwood or heartwood) and the dimensions of the same compartment. Measured $\mathrm{N}$ concentration = closed circle; measured $\mathrm{K}$ concentration = open triangle; measured Ca concentration = grey square; regression function for $\mathrm{N}=$ solid line; regression function for $\mathrm{K}=$ dashed line; regression function for Ca $=$ dotted line. Dimensional predicting variable = branch diameter $(\mathrm{m})$ or stem tissue (bark; sapwood; heartwood) thickness $(\mathrm{m})$. Branches were analyzed at the complete branch scale whereas the stem tissues (bark; phloem; sapwood; heartwood) were analyzed at the annual shoot scale. Nutrient concentration values are expressed as $\mathrm{mg} \mathrm{g}^{-1}$. The parameters of the regression functions are summarized in Table III. 


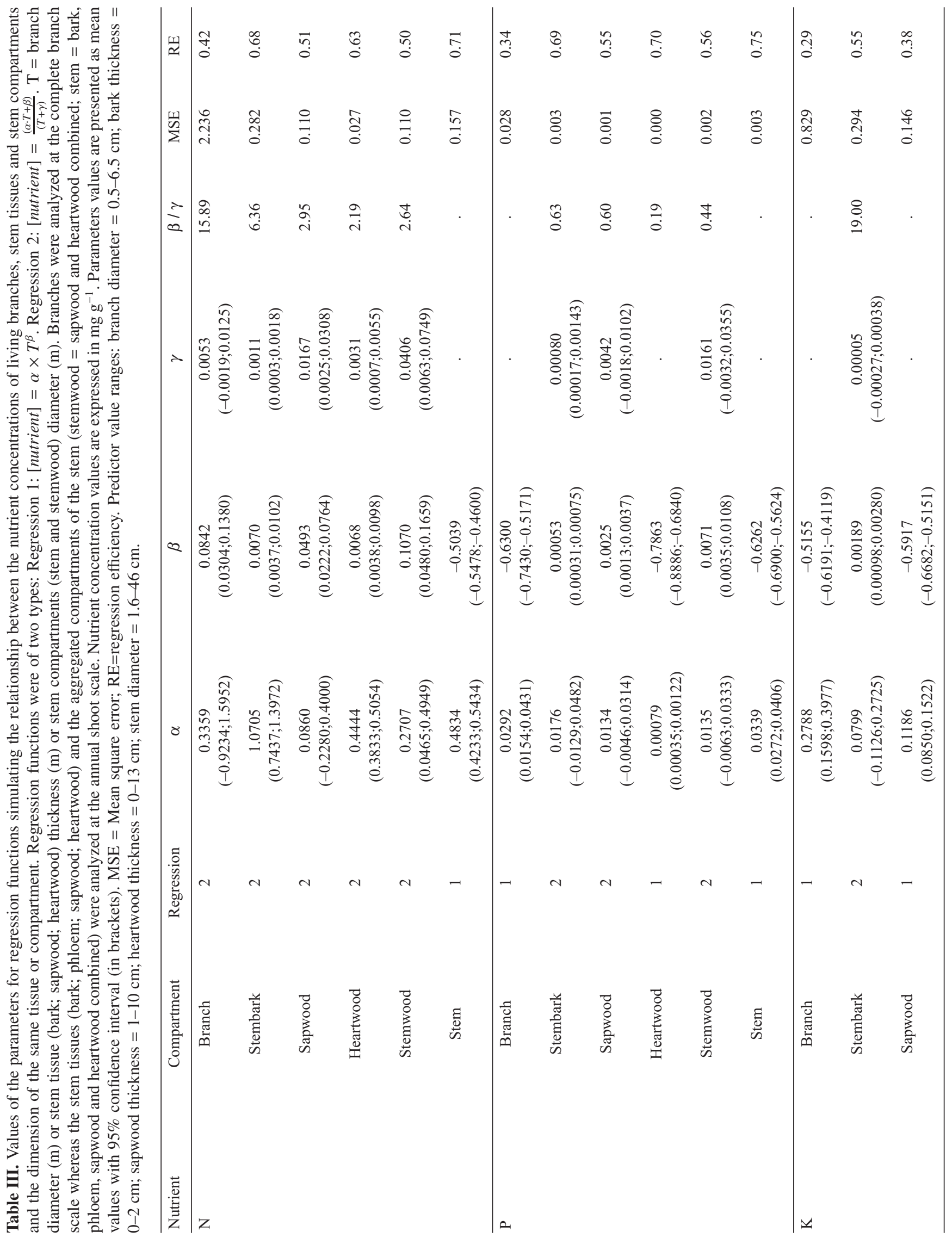




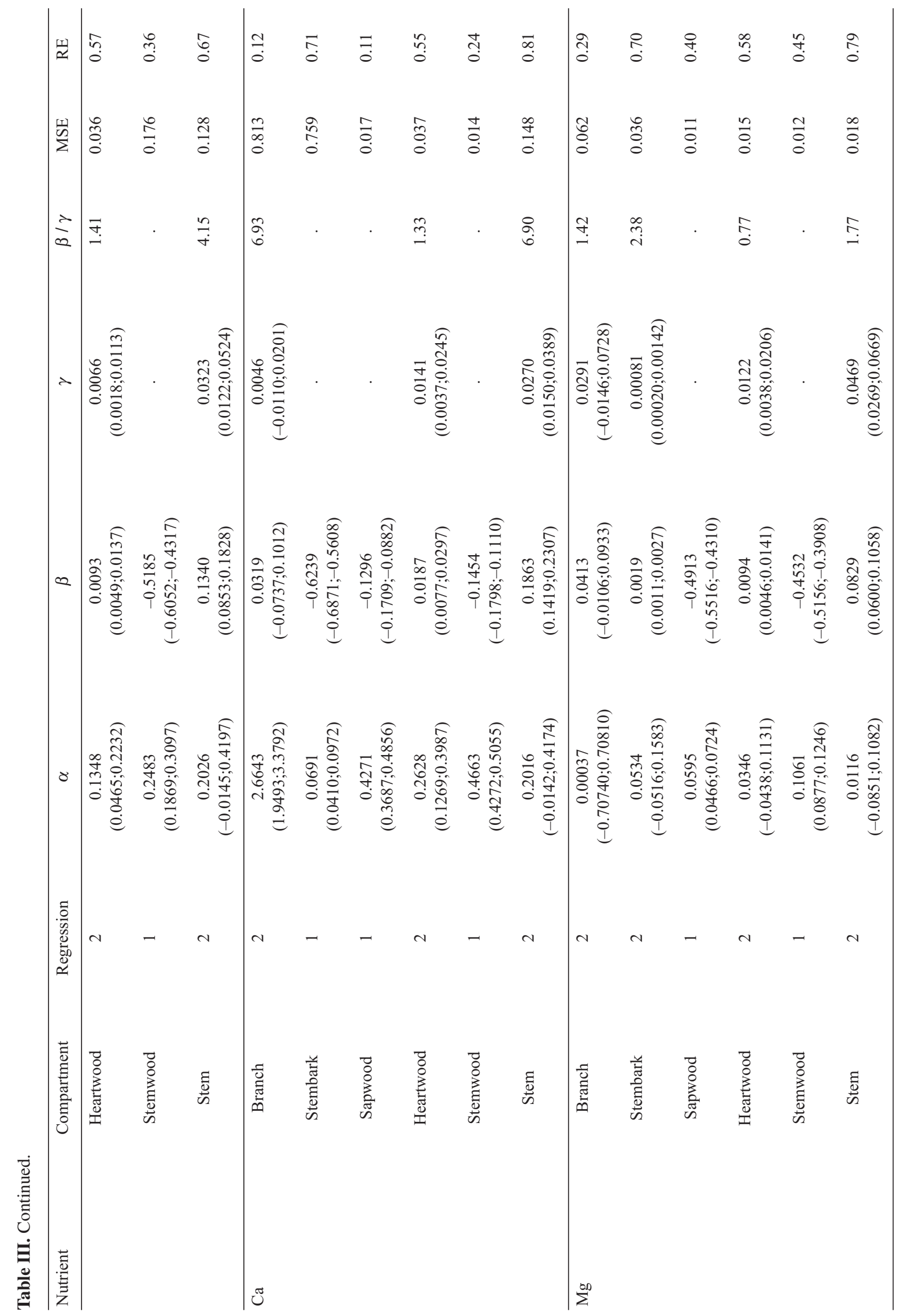




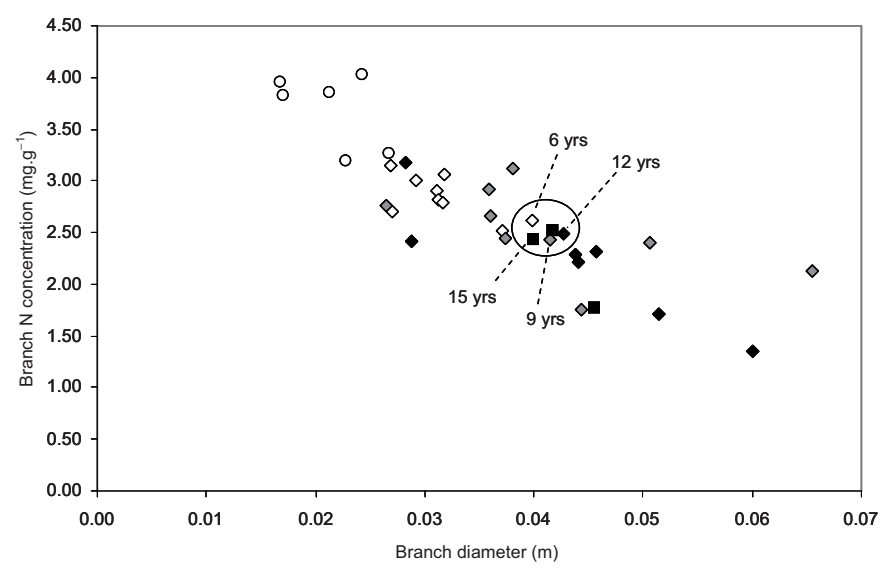

Figure 4. Relationship between $\mathrm{N}$ concentration of living branches and branch diameter in 32 year-old trees. Cambial age of the stem section supporting the living branch: $3 \mathrm{y}=$ open circle, $6 \mathrm{y}=$ open diamond, $9 \mathrm{y}=$ grey diamond, $12 \mathrm{y}=$ closed diamond, $15 \mathrm{y}=$ closed square. Dimensional predicting variable $=$ branch diameter (m). Branches were analyzed at the complete branch scale. Nutrient concentrations are expressed as $\mathrm{mg} \mathrm{g}^{-1}$.

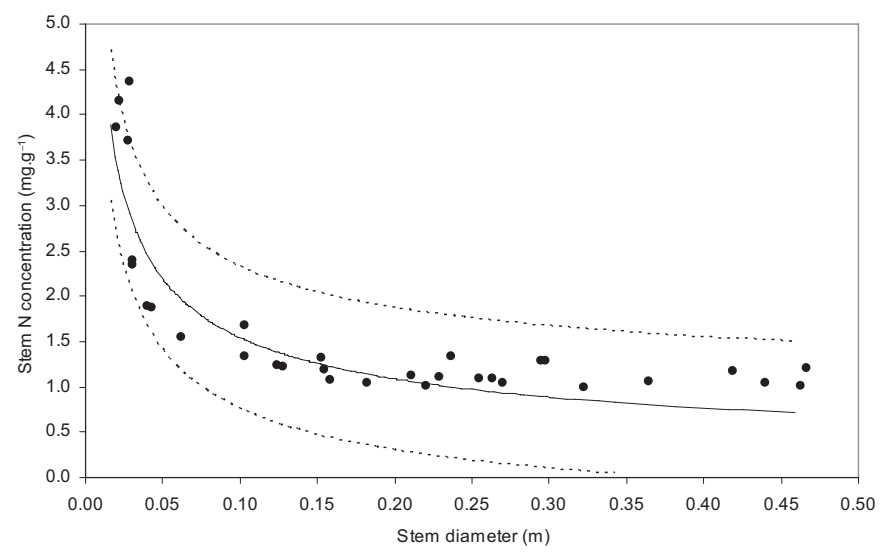

Figure 5. Validation of regression function predicting the $\mathrm{N}$ concentration of the stem compartment at the annual shoot scale from the stem diameter of the same annual shoot. Stem compartment $=$ all stem tissues combined. $\mathrm{N}$ concentration of the stem measured in annual shoots from the Bilos stand (50-years-old) = closed circle; regression function predicting the $\mathrm{N}$ concentration $\left(\mathrm{mg} \mathrm{g}^{-1}\right)$ of the stem at the annual shoot scale (established on the five other stands) $=$ solid line; $95 \%$ confidence interval of the regression $=$ dotted line.

$\left.0.57 \mathrm{mg}-\mathrm{N} . \mathrm{g}^{-1}\right)$ and older needles $\left(10.24 \pm 0.34 \mathrm{mg}-\mathrm{N} . \mathrm{g}^{-1}\right)$, but not for dead branches $\left(1.60 \pm 0.18 \mathrm{mg}-\mathrm{N} \cdot \mathrm{g}^{-1}\right)$. For stem phloem, the validation dataset showed $\mathrm{N}$ concentrations which decreased with increasing phloem thickness. This negative relationship contrasted with the constant value calculated from the calibration dataset. This discrepancy was due to the too narrow range of the predicting variable in our calibration dataset (phloem thickness $=1.5-3.0 \mathrm{~mm}$ ) compared to the validation dataset (phloem thickness $=0.8-3.1 \mathrm{~mm}$ ).

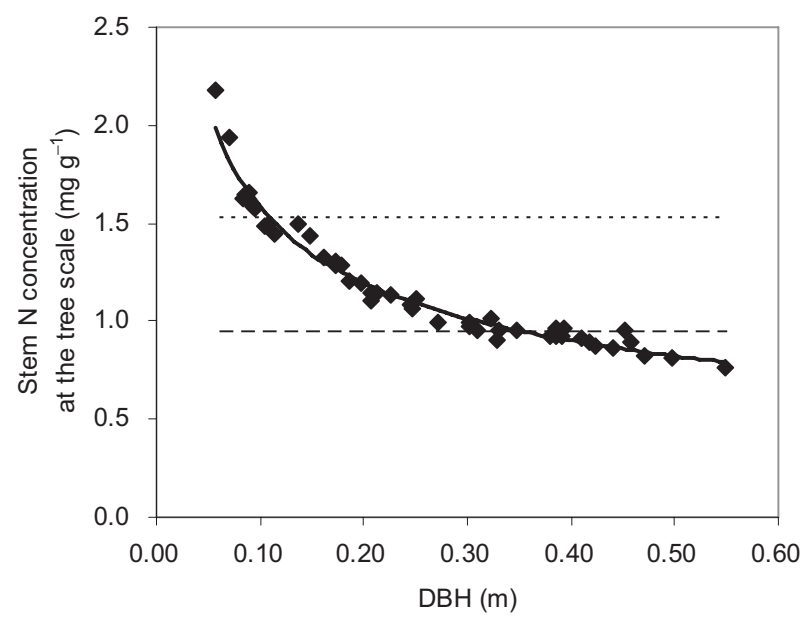

Figure 6. Relationship between the average $\mathrm{N}$ concentration of the stem (all stem tissues combined) at the tree scale and stem diameter at breast height. closed diamond $=$ average $\mathrm{N}$ concentration of the stem at the tree scale estimated according to regressions established for stem at the annual shoot scale; regression function between the $\mathrm{N}$ concentration of the stem at the tree scale and the stem diameter at breast height $(\mathrm{DBH})=$ solid line (see Tab. IV for details on the regression function and its parameters); average $\mathrm{N}$ concentration of the stem (non weighted arithmetic mean of all $\mathrm{N}$ concentration data for stems at the annual shoot scale of the study) = dotted line; average plateau value of the $\mathrm{N}$ concentration in stem sections (annual shoot scale; only samples with a diameter of the stem $\geq 15 \mathrm{~cm})=$ dashed line. Concentration values are expressed in $\mathrm{mg} \mathrm{g}^{-1}$. Range of validity of the regression: $\mathrm{DBH}=0.06-0.55 \mathrm{~m}$.

\subsection{Prediction of nutrient concentrations in the stem at the tree scale}

In most reports found in the literature, the authors only considered the mean nutrient concentration of the tree stem. Using the present dataset, we compared our mean nutrient concentrations (global mean values (Tab. II); mean plateau values (Fig. 3)) with the concentration calculated at the tree scale. The concentration calculated at the tree scale decreased with increasing stem diameter at breast height (for example of $\mathrm{N}$, see Fig. 6). As the mean concentrations of all stem sections (Tab. II) were calculated for all samples but without weighting by the section biomass, they overestimated the mean nutrient concentrations in the tree stem (dotted line; Fig. 6). The deviation was almost nil for 8 -year-old pines $(-3$ to $-7 \%$; mean deviation per nutrient) but increased steeply for older trees (40-year-old pines: +72 to $+106 \%)$. On the other hand, the mean plateau values tended to underestimate nutrient concentrations in the tree stem (dashed line; Fig. 6) for small trees (8year-old pines: $-41 \%$ to $-61 \%$ ) because they did not take into account the young sections of the stem. This shift decreased with increasing stem diameter until consistency was reached at around 26-32 years and older $(-16 \%$ to $+15 \%)$. The relationships between the nutrient concentration in the stem at the tree scale and the stem diameter at breast height were regressed according to the R1 regression form (Tab. IV). No confidence interval is given for the regression parameters because 
Table IV. Values of the parameters for regression functions simulating at the tree scale the relationship between the average nutrient concentrations of the stem and the diameter of the stem at the breast height $(\mathrm{DBH})$. Regression functions were as follows: [nutrient] = $\alpha \times D B H^{\beta} . \mathrm{DBH}=$ stem diameter at breast height $(\mathrm{m})$. The nutrient concentration values $\left(\mathrm{mg} \mathrm{g}^{-1}\right)$ of the stem compartment $($ stem $=$ bark, phloem, sapwood and heartwood combined) were calculated at the tree scale according to the concentration values of each annual shoot which were estimated with the regression functions established at the annual shoot scale (Tab. III).

\begin{tabular}{ccc}
\hline Nutrient & $\alpha$ & $\beta$ \\
\hline $\mathrm{N}$ & 0.6208 & -0.4066 \\
$\mathrm{P}$ & 0.0466 & -0.5036 \\
$\mathrm{~K}$ & 0.4275 & -0.4431 \\
$\mathrm{Ca}$ & 0.5389 & -0.4890 \\
$\mathrm{Mg}$ & 0.2020 & -0.4500 \\
\hline
\end{tabular}

the concentrations of the stem were already estimated according to the regressions established at the scale of the annual shoot (Tab. III).

\section{DISCUSSION}

\subsection{Distribution of nutrients among and within tissues}

\subsubsection{Distribution among tissues}

As has already been shown (Merino et al., 2005), nutrient concentrations vary greatly among tree tissues: (canopy; stem bark and phloem) > stemwood. Even within the stem, tissues ranked by nutrient concentration (Penninckx et al., 2001; André and Ponette, 2003) showed sapwood to contain higher concentrations than heartwood, at least of $\mathrm{N}, \mathrm{P}$ and $\mathrm{K}$ (Meerts, 2002). Differences between sapwood and heartwood can mainly be explained by the lack of physiological activity in heartwood and by the structural and chemical changes that occur during the formation of heartwood (Bergstrom, 2003). Generally speaking, there was a gradient of nutrient concentrations among tissues from the almost dead and very nutrientpoor heartwood to very active and nutrient-rich buds. The same hypothesis of a decrease in physiological activity (Warren, 2005) may also explain the differences in $\mathrm{N}, \mathrm{P}$ and $\mathrm{K}$ among needle age classes (Seillac, 1962; Wyttenbach and Tobler, 1988). Conversely, Ca concentrations in foliage increased from one-year-old to two-year-old needles $\left(\mathrm{Ndl1}<\mathrm{Ndl} 2^{+}\right.$), suggesting a general accumulation of this rather immobile nutrient with increasing needle age (Wyttenbach and Tobler, 1988). All these results are probably the consequence of the translocation behaviour of the nutrients concerned (see below).

\subsubsection{Distribution within each tissue}

Some authors reported vertical variations in nutrient concentrations in foliage (Lopez-Serrano et al., 2005) related to the effect of exposure to light (Warren and Adams, 2001). This result was not confirmed in the present study. This difference was probably due to the relatively low density of our pine stands $\left(<1600\right.$ stems.ha $^{-1}$ versus 5000-46000 stems.ha ${ }^{-1}$ for Lopez-Serrano et al., 2005) which, in our case, resulted in high light transmittance. Keay et al. (1968) did not observe a vertical gradient in nutrient concentrations in needles in a 13 year-old Pinus pinaster stand comprising 1950 stems.ha $^{-1}$. Thus, in open pine stands, it appears that nutrient concentrations in the foliage depend mainly on needle age, but not on the vertical position of the needles, tree age or stem cambial age. As this result depended on the local management of stands, our constant values should be used with caution outside the context of the present study.

In living branches, stem bark, and stemwood, there is a global decrease in concentration with increasing diameter or thickness of the compartment (André and Ponette, 2003; Rytter, 2002). This decrease is more pronounced for N, P and $\mathrm{K}$ than for $\mathrm{Mg}$ and particularly $\mathrm{Ca}$ (Finer and Kaunisto, 2000). As already mentioned by Rytter (2002), it is difficult to distinguish the effect of tree age from the effect of tree dimensions as the two are linked. However, in our study, when comparing trees or compartments of the same age but of different size, it appeared that nutrient concentrations were more related to dimensions than to tree age or to cambial age (Fig. 4). Our results indicate that nutrient distribution in the upper part of the stem of old trees is similar to that of the whole stem of younger trees of similar size. This is partially supported by the B26 method of sampling of living branches: the nutrient concentrations of the extremities of branches of 26-year-old trees were similar to those of complete branches of 8 to 32 -yearold trees of similar diameter (data not shown). In an intensive study of the stemwood of a Eucalyptus hybrid, Saint-André et al. (2002) showed that tree age influenced K and N concentrations. However, this result was mostly observed in the one-year-old rings. As we only studied bulk samples of wood for which the relative weight of the youngest ring was low, this would explain why we observed almost no effect of tree age.

Negative relationships between nutrient concentration and stem radius are commonly observed in trees (Rochon et al., 1998). Several processes could explain such a distribution. First, some compartments are composed of a few tissues that have different nutrient concentrations. For instance, branch bark presents much higher nutrient concentrations than branch wood (Young and Guinn, 1966). As the proportion of bark decreases with increasing branch diameter, concentrations in the whole branch decrease mathematically along the same dendrometric gradient. Secondly, some nutrients are highly translocated from old wood rings to younger rings. This pattern induces a decrease in nutrient concentration with increasing compartment dimension. Ring to ring translocation occurs mainly between the youngest rings (Colin-Belgrand et al., 1996) which is concordant with the plateau of nutrient concentration observed for the largest dimensions of the compartments (Figs. 1 and 2). Translocation concerns N, P, K and to a lesser extent - Mg more than Ca (Colin-Belgrand et al., 1996). The main hypothesis explaining the difference in behaviour between $\mathrm{N}, \mathrm{P}$ and $\mathrm{K}$ on one hand and $\mathrm{Ca}$ on the other 
hand is that the former are mostly located in mobilizable forms whereas the latter is mostly sequestered in permanent structures such as cell walls or lignin (Meerts, 2002) and presents a low solubility in phloem vessels. Beyond a certain value of the compartment dimension, at which the proportion of tissues was quite stable and nutrient translocation was insignificant, the mean nutrient concentration became relatively constant ("plateau value"). The mean value of the nutrient concentration can thus be directly used to estimate the nutrient content of the compartment. Mean plateau values should be used for adult trees instead of the $\alpha_{2}$ values for two reasons: (i) it was not possible to calculate the $\alpha_{2}$ parameter in all cases and (ii) $\alpha_{2}$ parameter is an extreme theoretical value and hence not representative of the whole range of plateau values. Indeed, the (plateau value $/ \alpha_{2}$ value) ratio was $2-15$ in most cases and even higher in the other cases.

\subsection{Validation of the predictive relationships}

An independent nitrogen dataset was used to test the fitted regressions and calculated constant concentrations. Results were satisfactory for most of the compartments of the living canopy and stem, showing that the estimated concentrations were reliable.

However, for three compartments, our estimates of nutrient concentrations could be still improved. For stem phloem, it appeared that our conclusion concerning a constant nitrogen concentration was due to the too narrow range of the predicting variable in the calibration dataset. The validation dataset was thus used to calculate the parameters of the $\mathrm{R} 1$ regression type $\left(\alpha_{1}=0.2123 ; \beta_{1}=-0.4608 ; r^{2}=0.81 ;\right.$ phloen thickness in $\mathrm{m})$. Estimates of the nitrogen concentration in stem heartwood showed some variability among sampling operations and more information on this compartment would improve the accuracy of the predictive relationship. Finally, the sampling design for dead branches appeared to be far too simple, as no compartment dimension was recorded (see Material and methods section). This was probably the main reason for the discrepancy between estimated and measured values and additional work is necessary concerning this compartment.

\subsection{Range of validity of the approach}

A preliminary study (Dumery, 1973) compared the nutrient concentration of Pinus pinaster stands in the various site classes in the same region as ours. This author did not observe any systematic and significant difference among the site classes. In our study, the stand used for the validation dataset was outside the range of age of the calibration dataset $(50 \mathrm{y}$ and 8-40 y, respectively) and had a very different growth rate. We can thus conclude that our results are reliable in different contexts in south-western France. Average nutrient concentrations for our stands are generally similar to values reported in literature for Pinus pinaster stands from other regions in the world (Tab. II). We can thus assume that the present regressions deliver reliable estimates of the nutrient contents of
Pinus pinaster in most pedological contexts and that nutrient concentrations are not greatly modified by the soil nutritive status.

One can also question the sensitivity of the nutrient concentrations of the tree to management of stand nutrition. Stemwood nutrient concentrations measured in adult trees through bulk sampling were found to be not significantly modified by NPK fertilization (Finer and Kaunisto, 2000; Heilman and Gessel, 1963), liming (Houle et al., 2002) or experimental soil acidification (DeWalle et al., 1999). This reveals a high degree of homeostatic control of tree chemistry for most elements (Smith and Shortle, 2001), even though some exceptions exist (e.g. Watmough et al., 1999). Conversely, fertilization has often been shown to have a significant effect on the nutrient composition of foliage and sometimes of branches and stembark (Heilman and Gessel, 1963; Nilsson and Wiklund, 1995). Overall, intensive nutrition management seems to mostly modify the canopy of a tree but to only slightly modify its trunk. Therefore, we can conclude that the reliability of our regressions probably follows the same pattern, and estimated nutrient concentrations of Pinus pinaster trunk are thus reliable and accurate, even though some slight interactions with the soil properties may exist. On the other hand, our regressions for the canopy should be used with caution.

\subsection{Estimation of the nutrient content of aboveground tree compartments}

Some compartments of the canopy (needles; buds) did not show any explainable variation of their nutrient concentrations. Hence, the stand nutrient content of these compartments can be estimated using constant concentration values and biomass estimates at the stand scale (e.g. for tree needles, Porté et al., 2000). For the other aboveground compartments, more detailed data on tree dimensions are required. Nutrient content of living branches can be estimated providing that the diameter of all branches is given by a branch model. This variable can be used to estimate both the biomass of the branch (Porté et al., 2002) and its nutrient concentrations. Similarly, the nutrient content of the trunk can be estimated if its diameter is available for various heights. For maritime pine stands, the tree growth model Pp3 (derived from Lemoine, 1991) coupled with a stem profile model gives the dimensions of the tree along the stem for all trees in the stand and at any age.

These proposals are an improvement on the model approach proposed by Rodriguez-Soalleiro et al. (2007), notably for young trees and for the canopy at any tree age. Indeed, our results confirm that the largest branches (diameter $\geq 2.5 \mathrm{~cm}$ ) and stem segments (diameter $\geq 15 \mathrm{~cm}$ ) have a fairly constant nutrient concentration. As these compartments represent the main contribution to the total aboveground biomass of the adult tree, logically the mean nutrient concentration at the tree scale should also be relatively constant. However, in the case of young trees, the proportion of tissues with a constant concentration is lower. Therefore, using a single value for nutrient concentration leads to significant errors in estimation (up to $106 \%$ in our case). Using the relationships described in the 
present study would improve the accuracy of estimates of the nutrient content of Pinus pinaster stands. For this species, we also proposed regressions to estimate the mean concentration in the stem at the tree scale (Tab. IV). The reliability of the latter regressions is not certain in contexts that are different from ours as the distribution of the stem biomass among the annual shoots depends on at least the stand management (see comments about the direct allometric relationships in the Introduction section). Therefore, the dimensional relationship approach should be applied at the annual shoot scale (Tab. III), if possible.

The objective of the present work was to link tree nutrient concentration with easily accessible variables like tree dimensions. Results showed that this goal was reachable. The reliability of the regressions appears to be satisfactory for aboveground nutrient content of Pinus pinaster. More field work and analyses are required to determine similar relationships for belowground tree compartments. The study of Gordon and Jackson (2000) already supported the hypothesis that negative relationships also exist between root diameter and root nutrient concentrations. More generally speaking, the dimensional relationship approach seems to be applicable to most woody species. However, performing such a detailed study is costly and very time consuming. It is consequently unrealistic to conclude that this approach should be used for all the tree species of commercial interest. An intermediate solution between using a single concentration value and building complete dimensional regressions could be estimating mean concentration values for a few dimension classes of each tree compartment. For instance, André and Ponette (2003) proposed mean values of nutrient concentration for six diameter classes of living branches in two hardwood species. Coupling such mean values with a model of biomass which also uses several classes of branches as a function of their diameter (e.g. Bravo et al., 2008 for Pinus pinaster) would enable estimation of the nutrient content of the stand in a realistic and reasonable accurate way.

Acknowledgements: It is not possible to cite all those who worked on the present study. We sincerely thank them all for enabling us to complete this project and particularly the technical staff of the following INRA teams: UE-Hermitage, UR-EPHYSE, US-USRAVE and UMR-TCEM (Christian Barbot and Sylvie Niollet). We are grateful to CAFSA and "France-Forêts" who allowed us access to their stands. This study was partially funded by GIP-ECOFOR and CTBA with the help of Jean-Michel Carnus (INRA). General data on maritime pine were kindly provided by Pierre Alazard (FCBA). We are grateful to Daphne Goodfellow for revising the English and to two anonymous reviewers for their useful comments. We dedicate this paper to Bernard Lemoine who initiated the Berganton field experiment but unfortunately passed away before it was completed.

\section{Appendix 1. Allometric relationships used to estimate bark, phloem and heartwood thickness.}

$$
T_{\text {bark }}=\left(\left(0.977 \times\left(\frac{D_{\text {stem }}}{D B H}\right)\right)-0.082\right) \times T_{\text {bark-BH }}
$$

$$
\begin{aligned}
T_{\text {phloem }}= & (0.00741 \times C U B)-\left(0.00025 \times A G E_{\text {cambium }}\right) \\
& -(0.00019 \times H t)-\left(5.88 \cdot E^{-7} \times\left(\frac{H t_{\text {tree }}}{D B H}\right)\right)+0.00587 \\
& T_{\text {heartwood }}=0.099 \times\left(1-\left(\exp ^{-24.903 \times\left(D_{\text {stem }}^{2.6796}\right)}\right)\right)
\end{aligned}
$$

$\mathrm{AGE}_{\text {cambium: }}$ : Stem cambium age (y). CUB: Circumference under bark (m). $D_{\text {stem: }}$ Stem diameter $(m)$. DBH: Stem diameter at breast height $(\mathrm{m})$. Ht: Height of the sample in the stem (m). $\mathrm{Ht}_{\text {tree }}$ : Tree height (m). $\mathrm{T}_{\text {bark }}$ : Bark thickness (m). $\mathrm{T}_{\text {bark-BH}}$ : Stem bark thickness at breast height $(\mathrm{m}) . \mathrm{T}_{\text {heartwood }}$ : Stem heartwood thickness $(\mathrm{m})$. $\mathrm{T}_{\text {phloem }}$ : Stem phloem thickness (m).

\section{REFERENCES}

André F. and Ponette Q., 2003. Comparison of biomass and nutrient content between oak (Quercus petraea) and hornbeam (Carpinus betulus) trees in a coppice-with-standard stand in Chimay (Belgium). Ann. For. Sci. 60: 489-502.

Augusto L. and Bert D., 2005. Estimating stemwood nutrient concentration with an increment borer: a potential source of error. Forestry 78: 451-455.

Augusto L., Ranger J., Ponette Q., and Rapp M., 2000. Relationships between forest tree species, stand production and stand nutrient amount. Ann. For. Sci. 57: 313-324.

Bergstrom B., 2003. Chemical and structural changes during heartwood formation in Pinus sylvestris. Forestry 76: 45-53.

Bert D. and Danjon F., 2006. Carbon concentration variations in the roots, stem and crown of mature Pinus pinaster (Ait.). For. Ecol. Manage. 222: 279-295.

Bravo F., Bravo-Oviedo A., and Diaz-Balteiro L., 2008. Carbon sequestration in Spanish Mediterranean forests under two management alternatives: a modeling approach. Eur. J. For. Res. 127: 225-234.

Colin-Belgrand M., Ranger J., and Bouchon J., 1996. Internal nutrient translocation in chestnut tree stemwood: III- Dynamics across an age series of Castanea sativa (Miller). Ann. Bot. 78: 729-740.

Dambrine E., Vega J.A., Taboada T., Rodriguez L., Fernandez C., Macias F., and Gras J.M., 2000. Bilans d'éléments minéraux dans de petits bassins versants forestiers de Galice (NW Espagne). Ann. For. Sci. 57: $23-38$

Daniel R.C., Lischer P., Theiller G., Fragoso M.A.C., and van Beusichem ML. (Eds.), 1993. Four new CII reference materials for the chemical analysis of plants: pine needles, oak leaves, barley-straw and applefruit. Optimization of plant nutrition: refereed papers from the Eighth International Colloquium for the Optimization of Plant Nutrition, 31 August-8 September 1992, Lisbon, Portugal, pp. 31-35.

De Walle D.R., Tepp J.S., Swistock B.R., Sharpe W.E., and Edwards P.J., 1999. Tree-ring cation response to experimental watershed acidification in West Virginia and Maine. J. Env. Qual. 28: 299-309.

Dumery B., 1973. Relation entre la nutrition minérale et la croissance du Pin maritime dans les principaux sites des Landes de Gascogne. Ph.D. thesis, Univ. Bordeaux, 175 p.

Fernandez-Prida C., 1977. Mineral composition of Pinus pinaster wood. Investigacion-y-Tecnica-del-Papel 14: 633-642.

Ferretti M., Udisti R., and Barbolani E., 1993. Mineral nutrients and trace metals in tree rings of Pinus sp. J. Anal. Chem. 347: 467-470.

Finer L. and Kaunisto S., 2000. Variation in stemwood nutrient concentrations in Scots pine growing on peatland. Scand. J. For. Res. 15: 424-432. 
Gordon W.E. and Jackson R.B., 2000. Nutrient concentrations in fine roots. Ecology 81: 275-280.

Heilman P.E. and Gessel S.P., 1963. The effect of nitrogen fertilization on the concentration and weight of nitrogen, phosphorus, and potassium in Douglas fir trees. Soil. Sci. Soc. Am. Proc. 27: 102-105.

Houle D., Duchesne L., Moore J.D., Laflèche M.R., and Ouimet R., 2002. Soil and tree-ring chemistry response to liming in a sugar maple stand. J. Env. Qual. 31: 1993-2000.

Ilomaki S., Nikinmaa E., and Makela A., 2003. Crown rise due to competition drives biomass allocation in silver birch. Can. J. For. Res. 33: 2395-2404.

Johnson C.E., Johnson A.H., and Siccama T.G., 1991. Whole-tree clearcutting effects on exchangeable cations and soil acidity. Soil Sci. Soc. Am. J. 55: 502-508.

Keay J. and Turton A.G., 1970. Distribution of biomass and major nutrients in a Marine Pine plantation. Aust. For. 34: 39-48.

Keay J., Turton A.G., and Campbell N.A., 1968. Some effects of nitrogen and phosphorus fertilization of Pinus pinaster in Western Australia. For. Sci. 14: 408-417.

Lemoine B., 1991. Growth and yield of maritime pine (Pinus pinaster Ait.): the average dominant tree of the stand. Ann. For. Sci. 48: 593611.

Lemoine B., Ranger J., and Gelpe J., 1988. Distributions qualitative et quantitative des éléments nutritifs dans un jeune peuplement de pin maritime (Pinus pinaster). Ann. Sci. For. 45: 95-116.

Lopez-Serrano F.R., de las Heras J., Gonzalez-Ochoa A.I., and GarciaMorote F.A., 2005. Effects of silvicultural treatments and seasonal patterns on foliar nutrients in young post-fire Pinus halenpensis forest stands. For. Ecol. Manage. 210: 321-336.

Meerts P., 2002. Mineral nutrient concentrations in sapwood and heartwood: a literature review. Ann. For. Sci. 59: 713-722.

Merino A., Balboa M., Rodriguez-Soalleiro R., and Alvarez Gonzalez J.G., 2005. Nutrient exports under different harvesting regimes in fast-growing forest plantations in southern Europe. For. Ecol. Manage. 207: 325-339.

Monge C., 1970. Variations de la teneur en composés azotés des organes végétatifs du Pin maritime. Ph.D. thesis, Univ. Bordeaux, 45 p.

Montero G., Ortega C., Cañellas I., and Bachiller A., 1999. Productividad aérea y dynamica de nutrientes en una repoblacion de Pinus pinaster Ait. Sometida a distintos regimenes de claras. Investig. Agrar. Sist. Recur. For., Special issue 1: 175-206.

Nilsson L.O. and Wiklund K., 1995. Nutrient balance and P, K, Ca, Mg, S and $\mathrm{B}$ accumulation in a Norway spruce stand following ammonium sulphate application, fertilization, irrigation, drought and $\mathrm{N}$-free fertilisation. Plant Soil 168-169: 437-446.

Nunez-Regueira L., Rodriguez-Anon J.A., Proupin J., Mourinon B., and Artiaga-Diaz R., 2005. Energic study of residual forest biomass using calorimetry and thermal analysis. J. Therm. Anal. Cal. 80: 457-464.

Penninckx V., Glineur S., Gruber W., and Herbauts J., 2001. Radial variations in wood mineral element concentrations: a comparison of beech and pedunculate oak from the Belgian Ardennes. Ann. For. Sci. 58: 253-260.

Porté A., Bosc A., Champion I., and Loustau D., 2000. Estimating the foliage area of maritime pine (Pinus pinaster Ait.) branches and crowns with application to modelling the foliage area distribution in the crown. Ann. For. Sci. 57: 73-86.

Porté A., Trichet P., Bert D., and Loustau D., 2002. Allometric relationships for branch and tree woody biomass of Maritime pine (Pinus pinaster Ait.). For. Ecol. Manage. 158: 71-83.

Ranger J., Allié S., Gelhaye D., Pollier B., Turpault M.P., and Granier A., 2002. Nutrient budgets for a rotation of a Douglas-fir plantation in the Beaujolais (France) based on a chronosequence study. For. Ecol. Manage. 171: 3-16.

Rochon P., Pare D., and Messier C., 1998. Development of an improved model estimating the nutrient content of the bole for four boreal tree species. Can. J. For. Res. 28: 37-43.

Rodriguez-Soalleiro R., Balboa-Murias M., Alvarez-Gonzalez J.G., and Merino-Garcia A., 2007. Evaluation through a simulation model of nutrient exports in fast-growing southern European pine stands in relation to thinning intensity and harvesting operations. Ann. For. Sci. 64: 375-384

Rytter L., 2002. Nutrient content in stems of hybrid aspen as affected by tree age and tree size, and nutrient removal with harvest. Biomass Bioenergy 23: 13-25.

Saint-André L., Laclau J.P., Deleporte P., Ranger J., Gouma R., Saya A., and Joffre R., 2002. A generic model to describe the dynamics of nutrient concentrations within stemwood across an age series of a Eucalyptus hybrid. Ann. Bot. 90: 65-76.

Seillac P., 1962. L'application du diagnostic foliaire à la sylviculture landaise. C.R. Acad. Agric. Fr. 48: 322-327.

Smith K.T. and Shortle W.C., 2001. Conservation of element concentration in xylem sap of red spruce. Trees 15: 148-153.

Thompson T.D., Morris L.A., Lee A.H., and Wells C.G., 1986. Estimates of nutrient removal, displacement and loss resulting from harvest and site preparation of a Pinus taeda plantation in the Piedmont of North Carolina. For. Ecol. Manage. 15: 257-267.

Warren C.R., 2005. Why does photosynthesis decrease with needle age in Pinus pinaster? Trees 20: 157-164.

Warren C.R. and Adams M.A., 2001. Distribution of N, Rubisco and photosynthesis in Pinus pinaster and acclimation to light. Plant Cell Environ. 24: 597-609.

Watmough S.A., Hutchinson T.C., and Sager E.P.S., 1999. The impact of simulated acid rain on soil leachate and xylem chemistry in a Jack pine (Pinus banksiana Lamb.) stand in northern Ontario, Canada. Water Air Soil Pollut. 111: 89-108.

Wyttenbach A. and Tobler L., 1988. The seasonal variation of 20 elements in 1 st and 2nd year needles of Norway spruce, Picea abies (L.) Karst. Trees 2: 52-64.

Young H.E. and Guinn V.P., 1966. Chemical elements in complete mature trees of seven species in Maine. TAPPI J. 49: 190-197. 